\title{
De Garengeot's hernia: a case of acute appendicitis in a femoral hernia sac
}

\author{
De Garengeot fitı̆̆ı: Femoral fitık kesesi içinde \\ bir akut apandisit olgusu
}

\section{Ceren ŞEN TANRIKULU, ${ }^{1}$ Yusuf TANRIKULU, ${ }^{2}$ Nezih AKKAPULU ${ }^{3}$}

The presence of an appendix vermiformis in a femoral hernia sac is called De Garengeot's hernia. It is a very rare clinical condition and requires emergency surgery. However, preoperative diagnosis of De Garengeot's hernia is difficult. Herein, we report a 58-year-old female who presented with sudden-onset painful swelling in the right groin region. Diagnosis was established based on computed tomography findings, and appendectomy with meshfree hernia repair was performed. The postoperative period was uneventful, and the histopathologic examination of the specimen revealed gangrenous appendicitis.

Key Words: Appendicitis; De Garengeot's hernia; femoral hernia; hernia.
Femoral fitık kesesi içerisinde apendiksin bulunması de Garengeot fitığı olarak adlandırılır. Bu klinik durum, oldukça nadir görülen ve acil cerrahi girişim gerektiren bir klinik durumdur ve De Garengeot fitığı tanısının ameliyat öncesi konulması oldukça zordur. Bu yazıda sunulan olgu sağ kasık bölgesinde aniden başlayan ağrısı olan 58 yaşında kadın hastadır. Tanı, bilgisayarlı tomografi bulguları ile konuldu ve apendektomiyle birlikte greftsiz fitık onarımı uyguland. Ameliyat sonrası komplikasyon gelişmedi. Histopatolojik inceleme gangrenli apandisit ile uyumluydu.

Anahtar Sözcükler: Apandisit; De Garengeot fitığı; femoral fitık; fitik.
The presence of appendix vermiformis in a femoral hernia sac is quite a rare entity. It was first described by Rene Jacques Croissant de Garengeot in the 18th century, and this entity was later designated as "De Garengeot's hernia". The incidence of this disease is estimated to range approximately from 0.5 to $5 \%$ and is seen more commonly in women. ${ }^{[1-3]}$

\section{CASE REPORT}

A 58-year-old female patient was admitted to our emergency clinic with the complaint of sudden onset of nausea, vomiting and painful swelling in the right groin region for the last 24 hours. The patient was hemodynamically stable, and clinical examination revealed a $3 \times 4 \mathrm{~cm}$ mass in the right groin region. She had tenderness over this mass, and it was irreducible on palpation. Her bowel sounds were normoactive, and there was no sign of acute abdomen. Her body temperature was $38^{\circ} \mathrm{C}$, and white blood cell count (WBC) was $14500 / \mathrm{mm}^{3}$; other laboratory findings were within normal limits. Abdominal computed tomography (CT) imaging was compatible with appendicitis in a femoral hernia sac (Fig. 1).

She was diagnosed with irreducible right femoral hernia. An emergent surgery was planned. Through a right suprainguinal incision, the inguinal canal was opened, and the transversalis fascia was transected. After the femoral hernia sac was found and isolated from surrounding structures, it was opened, and an inflamed and gangrenous appendix vermiformis was found in the sac (Fig. 2). The proximal tip of the ap-
Departments of ${ }^{1}$ Emergency Department, ${ }^{2}$ General Surgery, Erzurum Training and Research Hospital, Erzurum;

${ }^{3}$ Department of General Surgery, Muş State Hospital, Muş, Turkey.
Erzurum Bölge Eğitim ve Araştırma Hastanesi, ${ }^{1}$ Acil Tıp Kliniği ${ }^{2}$ Genel Cerrahi Kliniği, Erzurum;

${ }^{3}$ Muş Devlet Hastanesi, Genel Cerrahi Kliniği, Muş. 


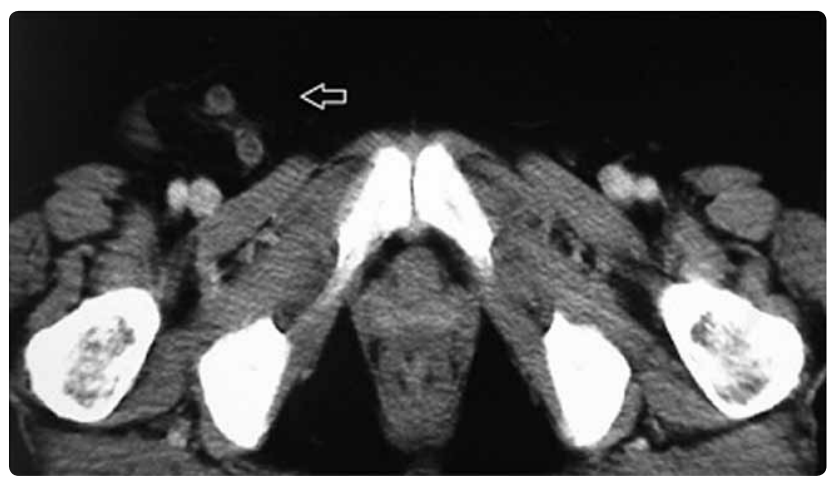

Fig. 1. Inflamed appendix in the hernia sac is shown with arrow on computed tomography scan.

pendix and cecum were found by tracing the appendix, and appendectomy was performed. The femoral hernia was repaired with McVay's technique after the hernia sac was excised intraabdominally. The incision was closed according to anatomical planes. Postoperative follow-up was uneventful, and the patient was discharged on the second postoperative day.

\section{DISCUSSION}

Rene Jacques Croissant de Garengeot first described the presence of the appendix vermiformis in a femoral hernia sac in 1731 , and this entity was later designated as "De Garengeot's hernia". ${ }^{[1,2]}$ The appendix in a femoral hernia sac may be of three types, as normal, inflamed or gangrenous. ${ }^{[4]}$

De Garengeot's hernia is quite a rare entity, and is seen more frequently in women than men, with a ratio of $3: 1$. The incidence of this disease is estimated to range approximately from 0.5 to $5 \%$ during femoral hernia repairs. ${ }^{[1,3]}$ Sharma et al. ${ }^{[5]}$ reported the mean age of patients with de Garengeot's hernia as 55 years.

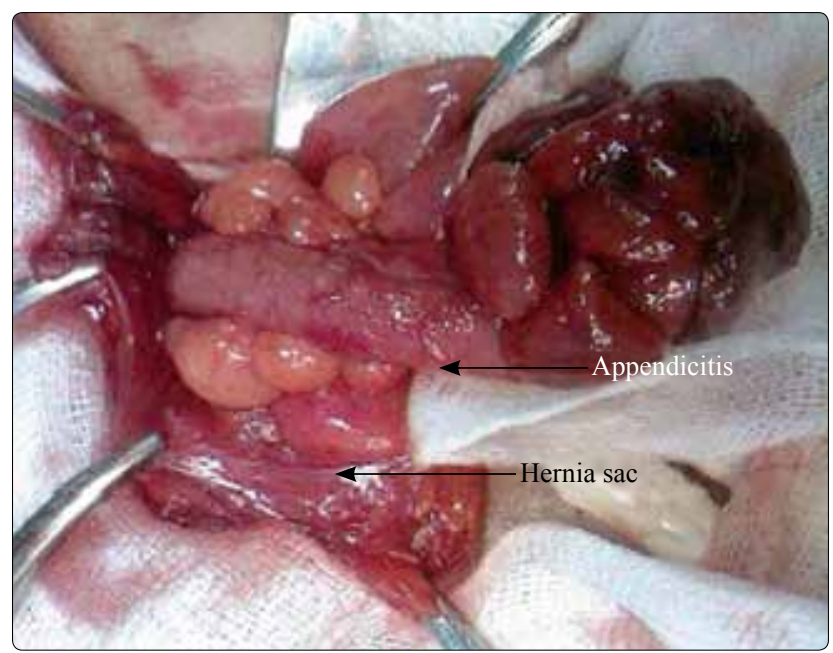

Fig. 2. Intra-operative view of De Garengeot's hernia. (Color figure can be viewed in the online issue, which is available at www.tjtes.org).
Many theories have been suggested for the pathogenesis of de Garengeot's hernia. The most widely accepted is the congenital theory, according to which, pelvic localization of the appendix vermiformis and rigid femoral ring predispose to the development of de Garengeot's hernia. ${ }^{[6-8]}$

De Garengeot's hernia is usually determined intraoperatively, but can be detected preoperatively by radiologic evaluation such as with CT. ${ }^{[9]}$ In the literature, $98 \%$ sensitivity and specificity have been reported for CT scan. ${ }^{[10]}$

Emergent surgery is the definitive treatment of de Garengeot's hernia. During surgery, appendectomy and femoral hernia repair are performed consecutively. Many tension or tension-free methods have been described for the repair of a femoral hernia according to the usage or not of prosthetic meshes. The most common method for femoral hernia is Cooper's ligament repair (McVay's technique). ${ }^{[5,11,12]}$ Mesh utilization should be avoided in the presence of inflammation and infection. The femoral hernia can be repaired with non-absorbable suture materials. ${ }^{[13]}$

In conclusion, acute appendicitis within a femoral hernia can be a life-threatening condition and always requires emergency surgery. Abdominal CT scan can be helpful in the diagnosis in the absence of abdominal findings of acute appendicitis. Appendectomy with mesh-free hernia repair is an acceptable treatment for de Garengeot's hernia.

Conflict-of-interest issues regarding the authorship or article: None declared.

\section{REFERENCES}

1. Akopian G, Alexander M. De Garengeot hernia: appendicitis within a femoral hernia. Am Surg 2005;71:526-7.

2. Tanner N. Strangulated femoral hernia appendix with perforated sigmoid diverticulitis. Proc R Soc Med 1963;56:11056.

3. Gurer A, Ozdogan M, Ozlem N, Yildirim A, Kulacoglu H, Aydin R. Uncommon content in groin hernia sac. Hernia 2006;10:152-5.

4. Fitzgerald E, Neary P, Conlon KC. An unusual case of appendicitis. Ir J Med Sci 2005;174:65-6.

5. Sharma H, Jha PK, Shekhawat NS, Memon B, Memon MA. De Garengeot hernia: an analysis of our experience. Hernia 2007;11:235-8.

6. D'Ambrosio N, Katz D, Hines J. Perforated appendix within a femoral hernia. AJR Am J Roentgenol 2006;186:906-7.

7. Nguyen ET, Komenaka IK. Strangulated femoral hernia containing a perforated appendix. Can J Surg 2004;47:68-9.

8. Temple CL, Huchcroft SA, Temple WJ. The natural history of appendicitis in adults. A prospective study. Ann Surg 1995;221:278-81.

9. Zissin R, Brautbar O, Shapiro-Feinberg M. CT diagnosis of acute appendicitis in a femoral hernia. Br J Radiol 2000;73:1013-4. 
10. Rao PM, Rhea JT, Novelline RA, Mostafavi AA, McCabe CJ. Effect of computed tomography of the appendix on treatment of patients and use of hospital resources. N Engl J Med 1998;338:141-6.

11. Carey LC. Acute appendicitis occurring in hernias: a report of 10 cases. Surgery 1967;61:236-8.
12. Rose RH, Cosgrove JM. Perforated appendix in the incarcerated femoral hernia. A place for preperitoneal repair. N Y State J Med 1988;88:600-2.

13. Korenkov M, Paul A, Troidl H. Color duplex sonography: diagnostic tool in the differentiation of inguinal hernias. $\mathrm{J}$ Ultrasound Med 1999;18:565-8. 